\title{
Yersinia pestis and plague: an updated view on evolution, virulence determinants, immune subversion, vaccination, and diagnostics
}

\author{
Christian E. Demeure $\mathbb{1}^{1} \cdot$ Olivier Dussurget ${ }^{1,2} \cdot$ Guillem Mas Fiol $\mathbb{1}^{1,2} \cdot$ Anne-Sophie Le Guern ${ }^{1,3,4} \cdot$ Cyril Savin $^{1,3,4}$ • \\ Javier Pizarro-Cerdá $\mathbb{D}^{1,3,4}$
}

Received: 28 February 2019 / Accepted: 18 March 2019 / Published online: 3 April 2019

(c) The Author(s) 2019. This article is published with open access

\begin{abstract}
Plague is a vector-borne disease caused by Yersinia pestis. Transmitted by fleas from rodent reservoirs, Y. pestis emerged $<6000$ years ago from an enteric bacterial ancestor through events of gene gain and genome reduction. It is a highly remarkable model for the understanding of pathogenic bacteria evolution, and a major concern for public health as highlighted by recent human outbreaks. A complex set of virulence determinants, including the Yersinia outer-membrane proteins (Yops), the broad-range protease Pla, pathogen-associated molecular patterns (PAMPs), and iron capture systems play critical roles in the molecular strategies that $Y$. pestis employs to subvert the human immune system, allowing unrestricted bacterial replication in lymph nodes (bubonic plague) and in lungs (pneumonic plague). Some of these immunogenic proteins as well as the capsular antigen F1 are exploited for diagnostic purposes, which are critical in the context of the rapid onset of death in the absence of antibiotic treatment (less than a week for bubonic plague and $<48 \mathrm{~h}$ for pneumonic plague). Here, we review recent research advances on $Y$. pestis evolution, virulence factor function, bacterial strategies to subvert mammalian innate immune responses, vaccination, and problems associated with pneumonic plague diagnosis.
\end{abstract}

\section{Introduction}

Plague is a vector-borne illness transmitted by fleas to a variety of wildlife rodents, which represent natural reservoirs for the disease in a wide range of habitats around the world [1]. The etiological agent of plague is the Gramnegative bacterium Yersinia pestis [2], discovered by the Institut Pasteur, bacteriologist Alexandre Yersin during a plague outbreak in Hong Kong in 1894 [3]. Plague has impacted the history of humankind through several pandemics that have initially spread from Central Asia to Africa

Javier Pizarro-Cerdá

javier.pizarro-cerda@pasteur.fr

Yersinia Research Unit, Institut Pasteur, F-75724 Paris, France

2 Université Paris-Diderot, Sorbonne Paris Cité, F-75013 Paris, France

3 National Reference Laboratory 'Plague \& Other Yersiniosis', Institut Pasteur, F-75724 Paris, France

4 World Health Organization Collaborating Research \& Reference Centre for Yersinia, Institut Pasteur, F-75724 Paris, France and Europe, and plague has reached every continent during the last 150 years [4]. In the 21st century, plague is present in Asia, Africa and America [5], and recent outbreaks in Uganda [6], China [7], Democratic Republic of Congo [8], and Madagascar $[9,10]$ remind that plague is still a major public health concern.

$Y$. pestis is highly similar on a genomic level to the enteric pathogen $Y$. pseudotuberculosis; however, a series of gene gain and gene loss events have led to the appearance of markedly different mechanisms of disease as well as niche preference and lifestyle [11]. $Y$. pestis displays a quite unique set of virulence factors that allow successful infection of fleas and subversion of immune responses in mammalian hosts, leading to rapid host death in the absence of adequate treatment. In this article, we review recent advances in plague research, particularly in the fields of evolution, virulence determinants, and subversion of mammalian immune responses, as well as an overview of the critical aspects of vaccination and pneumonic plague diagnosis. For other aspects of $Y$. pestis infection, such as $Y$. pestis adaptation to the flea, see, e.g., the review by Hinnebusch et al. [12]. 


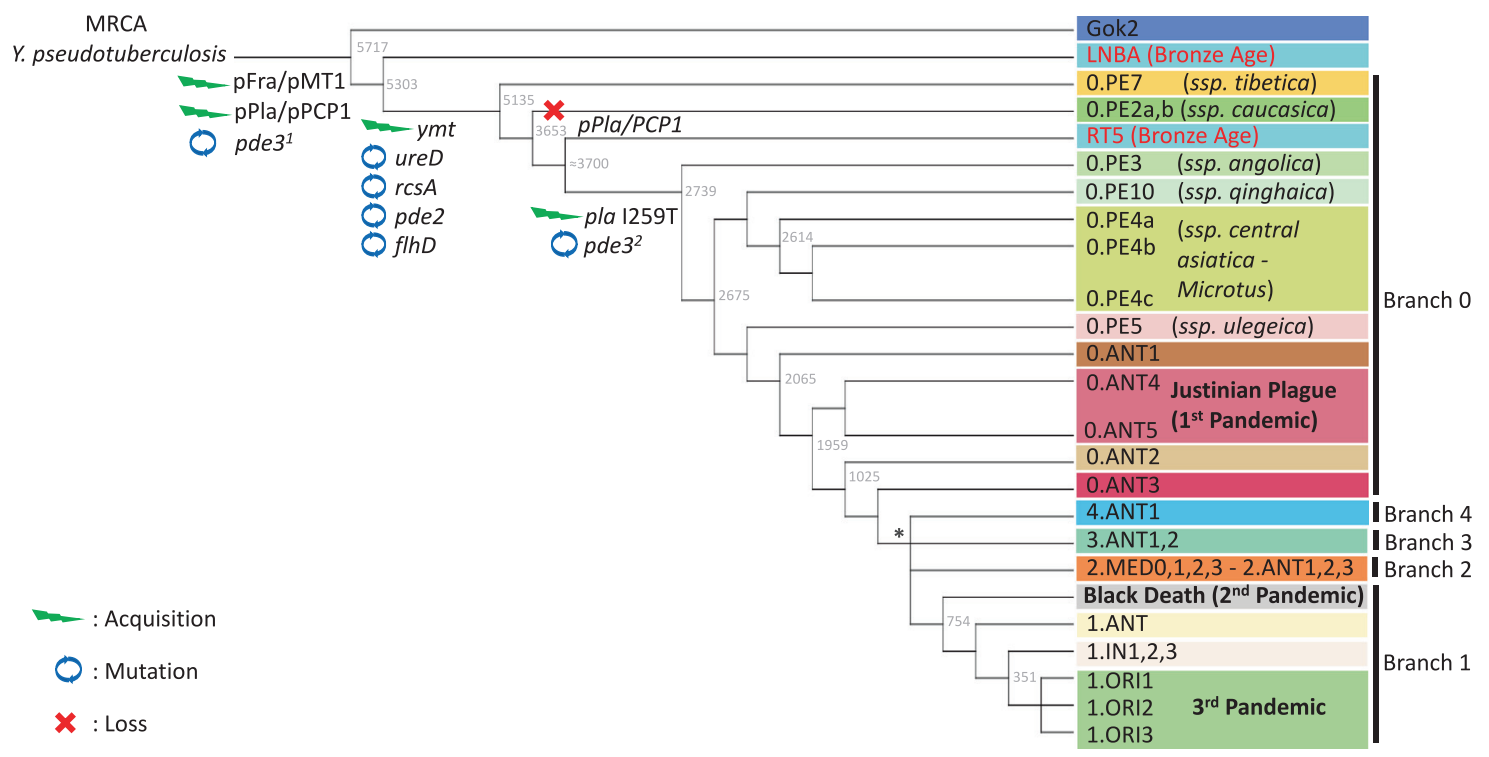

Fig. 1 Yersinia pestis phylogenetic tree. Schematic representation of the $Y$. pestis genealogy, including previously described phylogenetic branches (0-4) and biovars (ANT: Antiqua, MED: Medievalis, ORI: Orientalis, IN: Intermediate, PE: Pestoides, including Microtus isolates), as well as six novel Pestoides clusters [25]. The length of the branches does not reflect the evolutionary time. Nodes from branch 3 , branch 2 and branch 1.IN were collapsed for simplicity. The node indicated as an asterisk marks the polytomy known as the «Big Bang», which gave rise to branches $1-4$. The three historically recorded plague pandemics are presented in bold next to their associated phylogenetic lineages. The key gene gain and inactivation events in the

\section{Emergence and evolution of Yersinia pestis}

Insights into $Y$. pestis phylogeny are emerging from ancient DNA (aDNA) paleo-genomic studies, which have been positively impacted by the development of high-throughput, "next-generation" DNA sequencing (NGS) technologies, together with an impressive decline in sequencing costs. The recovery of $Y$. pestis DNA from the teeth of prehistoric individuals has uncovered the branching of independent lineages throughout Eurasia in the Neolithic, and allowed to accurately estimate that $Y$. pestis diverged from $Y$. pseudotuberculosis around 5700-6000 years ago (ya) [13-16]. This emergence was characterized by the acquisition of the two virulence-associated plasmids $\mathrm{pFra} / \mathrm{pMT} 1$ and $\mathrm{pPla} /$ pPCP1 and by the inactivation (promoter mutation) of the virulence-associated gene $p d e 3[15,17]$.

Whole-genome-based phylogenies have defined a fivebranch population structure for $Y$. pestis [18], following the previously described nomenclatures that termed the lineages according to their phylogenetic branch (0-4) plus the biovar abbreviation: ANT (biovar Antiqua), MED (Medievalis), ORI (Orientalis), IN (Intermediate), and PE (Pestoides, including Microtus isolates). An early divergence event occurred between 5000 and $5700 \mathrm{ya}$, giving origin to the most basal $Y$. pestis lineages persisting today (0.PE7 and 0 . evolution of $Y$. pestis from $Y$. pseudotuberculosis are displayed. These events include the acquisition of two virulence-associated plasmids (pFra/pMT1 and pPla/pPCP1), the gain of Yersinia murine toxin (ymt) in the pFra/pMT1 plasmid, as well as by the inactivation of the virulence-associated genes pde3 ( ${ }^{1}$ promoter mutation; ${ }^{2}$ inactivating mutation), ureD, $r c s A$, $f h D$, and pde2. The aftermath of these molecular changes gave rise to the $Y$. pestis' flea-borne transmission and thereby the ability to cause bubonic plague. The acquisition of the I259T mutation in the plasminogen activator (Pla), a key virulence factor responsible for the fulminant lung infection specific of $Y$. pestis, is also presented in the phylogeny

PE2), and to two extinct Neolithic and Bronze Age lineages (Gok2 and LNBA, respectively) [14]. These latter ones appeared to have functional variants of the virulenceassociated genes ureD, $r c s A$, flhD, and pde2 as well as to lack the Yersinia murine toxin encoded by the ymt gene (Fig. 1). The acquisition of ymt [17] and inactivation of ureD, $r c s A$, $f h D$, pde 2 , and $p d e 3$ critically contributed to the transmissibility of $Y$. pestis by fleas [19]. Interestingly, the plasminogen activator $\mathrm{Pla}$, a key virulence factor responsible for the fulminant lung infection specific of $Y$. pestis, was carried by Gok2, LNBA, 0.PE2, and 0.PE7 lineages in its ancestral form (I259), which has been associated with reduced bacterial dissemination in mammals [20]. This suggests that these strains may have had a limited flea-borne transmissibility and a reduced invasiveness within the host $[13,15]$.

A second expansion event around 4000 ya gave rise to an extinct Bronze Age lineage (RT5) and to lineages persisting to the present day: 0.PE4 (microtus) and the diverse lineages that led to all known plague pandemics [16]. The ancestor in this polytomy incorporated ymt and had the derived, inactive forms of $u r e D, r c s A$, $f h D$, and $p d e 2$, suggesting that the flea-mediated transmission mechanism causing bubonic plague evolved as early as 5000 ya [16]. The frequent presence of $Y$. pestis among Neolithic human 
remains indicates that this pathogen was prevalent and virulent, hypothesizing the existence of prehistoric plague pandemics [14]. Several models for early plague dispersion have been proposed $[13,14,16]$, although the exact birthplace of the successful $Y$. pestis lineage that led to the historically recorded pandemics remains unclear.

Paleo-genomic studies also provided unambiguous evidence confirming the presence of $Y$. pestis in two historically recorded plague pandemics: the Justinian's Plague (68th centuries) $[21,22]$ and the second plague pandemic (14-18th centuries) including the infamous Black Death $[23,24]$. The phylogenetic reconstruction of Justinian's Plague aDNA revealed novel, extinct Justinian lineages ( 0 . ANT4 and 0.ANT5) that branched between current 0.ANT1 and 0.ANT2 lineages, inaugurating independent lineages from strains associated with subsequent pandemics [22]. The wide distribution of 0 .ANT strains (0.ANT3 and the newly found 0.ANT5 population) within the high-mountain foci from Kyrgyzstan suggests a Central Asian origin for the Justinian's Plague pandemic [25]. In contrast to the first plague pandemic genomes, all recovered Black Death strains cluster at the root of branch 1, near a big bang polytomy that gave rise to most of the extant strain diversity $[18,26]$, including the lineages responsible for the Modern plague pandemic [22].

Several scenarios have been proposed to explain the transmission dynamics and persistence of plague in Europe after its introduction from Central/Eastern Asia during the Black Death. Initial paleo-genomic analyses using medieval $Y$. pestis genomes suggested that different bacterial clones were responsible for the second pandemic [24], proposing that plague was repeatedly introduced in Western Europe from reservoirs located in Eastern Europe/Central Asia [27] and spread via commercial trade routes and human migrations [28]. Other studies have found limited $Y$. pestis diversity during the second pandemic and propose a different scenario, in which plague may have established in natural rodent-based foci within Europe that evolved and persisted until the 18th century, spreading eastward back to Central and East Asia to become the source of the contemporary epidemics $[29,30]$. A recent study combining historical, archeological, and genomic data has reevaluated all previously published Medieval strains together with five novel $Y$. pestis genomes, and infers different waves of introduction of plague to Western Europe during medieval times [26]. Both long-term persistence together with multiple introductions might have shaped the dynamics of plague during the second pandemic [31], which could have also been transmitted by vectors that were different from those of rodents, such as human ectoparasites [32].

The third pandemic originated around 1855 in the Chinese province of Yunnan with the emergence of the biovar Orientalis strains, which belong to the 1.ORI branch. From this origin, plague spread worldwide via steamships carrying infected rats and is nowadays present in Asia, Africa, and America [4]. The transmission dynamics in the third pandemic were characterized by single introduction events, followed by a rapid expansion and settlement in local rodent reservoirs, which allowed a rodent-flea-rodent transmission cycle. This combination seems essential for plague establishment in newly colonized countries. For instance, this scenario took place with the introduction of plague in Brazil through the seaport of Santos, Sao Paulo in 1899 or in Toamasina, the main seaport of Madagascar, in 1898. Local settlement and expansion explain the observed diversity in the different 1.ORI lineages (1.ORI1, 1.ORI2, and 1.ORI3), each one representing a large wave of $Y$. pestis spread [4, 33-35]. The characterization of strains from extant natural plague foci has also contributed to sketch the historical transmission and the genealogy of $Y$. pestis. In light of the recent genotyping of 359 modern $Y$. pestis strains from the natural plague foci in the former Soviet Union countries, an update of the intraspecific taxonomy was proposed [25] (Fig. 1). This new population structure defined seven subspecies: the ssp. pestis, which includes the vast majority of virulent lineages that participated in the historically recorded pandemics (ANT, MED, ORI, and possibly, IN too); as well as six other clusters, including ssp. caucasica-0.PE2, ssp. angolica-0.PE3, ssp. central asiatica-0.PE4, spp. tibetica-0.PE7, ssp. ulegeica-0.PE5, and ssp. qinghaica -0. PE10.

\section{Yersinia pestis virulence determinants}

Plague prevention requires a complete understanding of $Y$. pestis complex pathogenesis, which relies on a finely regulated arsenal of virulence determinants [36]. Among them, the best characterized ones are the Yersinia outermembrane proteins (Yops), which constitute an array of effectors directly translocated into host cells through a type 3 secretion system (T3SS) [37-39]. The T3SS is encoded in the Yersinia virulence plasmid $\mathrm{pYV} / \mathrm{pCD} 1$, which is also present in the enteric pathogens $Y$. pseudotuberculosis and $Y$. enterocolitica. As previously mentioned, the emergence of $Y$. pestis from $Y$. pseudotuberculosis is associated with the acquisition of the pFra and pPla plasmids, which encode critical virulence factors (see below), as well as major gene loss (gene deletions, SNP-based, or phase-variable/mutation-based pseudogenes) that had a major impact in adaptation to the flea vector [11]. Here, we will review virulence determinants for mammalian hosts.

Yops have been shown to play pleiotropic roles during infection: they inhibit Rho GTPases and disrupt the actin cytoskeleton in order to inhibit phagocytosis, they downregulate the production of pro-inflammatory cytokines, and 


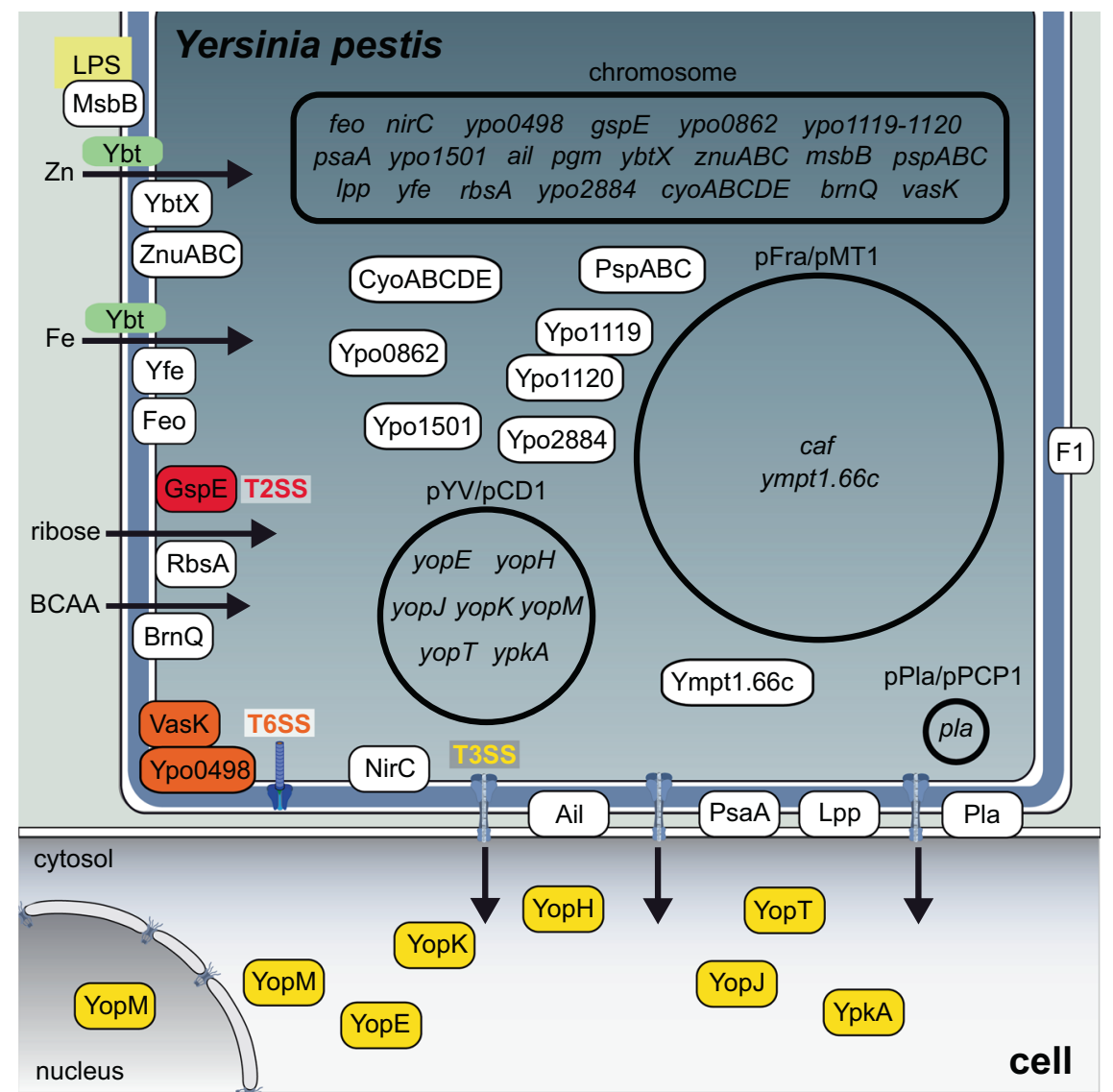

Fig. 2 Yersinia pestis virulence determinants. $Y$. pestis requires the three well-characterized virulence plasmids $\mathrm{pYV} / \mathrm{pCD} 1, \mathrm{pPla} / \mathrm{pPCP} 1$, and $\mathrm{pFra} / \mathrm{pMT} 1$, as well as chromosomally encoded virulence factors to cause disease. Examples of cytoplasmic, cell-surface associated, and secreted virulence factors are shown. The infectious process involves adhesion to host cells mediated by Braun lipoproteins Lpp and proteins such as Ail, PsaA, and Pla. Yop effectors, including YopH, YopE, YopT, YopJ, YpkA, YopM, and YopK, are subsequently delivered through the T3SS to trigger apoptosis, inhibit phagocytosis, and block cytokine production. LPS modification and the capsular antigen F1 encoded by the caf gene further contribute to Yersinia immune escape. The expression of many of these virulence determinants is induced during the transition from the temperature of the flea midgut $\left(26^{\circ} \mathrm{C}\right)$ to that of the mammalian host $\left(37^{\circ} \mathrm{C}\right)$. Y . pestis survival in the host

they induce cell death by multiple sophisticated mechanisms [40] (Fig. 2) (see also next section). For example, the tyrosine phosphatase YopH dephosphorylates focal adhesion complex proteins of immune cells [41]. YopE mimics GTPase-activating proteins (GAP) to downregulate host cell Rho GTPases [42]. The cysteine protease YopT cleaves and releases membrane-bound Rho GTPases [43]. YopJ is an acetyltransferase blocking both mitogen-activated protein kinase (MAPK) and nuclear factor- $\mathrm{KB}(\mathrm{NF}-\mathrm{\kappa B})$ signaling, inhibiting the production of pro-inflammatory cytokines $[44$, 45]. The serine/threonine kinase YpkA targets actinregulating proteins and keeps Rho GTPases inactive through its guanine nucleotide dissociation inhibitor (GDI) requires efficient metal acquisition systems. The yersiniabactindependent iron uptake system is encoded in the high-pathogenicity island within the pigmentation chromosomal locus pgm. Other metal transport systems, including YbtX, ZnuABC, Yfe, and Feo, also play a role in infection. Additional virulence factors have been identified by signature-tagged mutagenesis, "per-pool" mutant screening, or in vivo transcriptional profiling, e.g., YMPY1.66c, BrnQ, RbsA, GspE, NirC, CyoABCDE, PspABC, Ypo0862, Ypo1119, Ypo1120, Ypo1501, and Ypo 2884. BCAA: branched-chain amino acids, Fe: iron, LPS: lipopolysaccharide, T2SS: type-two secretion system, T3SS: type-three secretion system, T6SS: type-six secretion system, Ybt: yersiniabactin, Yop: Yersinia outer-membrane protein, Zn: zinc. Components of the illustration are not drawn to scale

domain [46]. YopM binds caspase-1 to arrest inflammasome assembly and activation [47], and behaves as a nucleomodulin modifying Interleukin-10 mRNA levels [48]. It is also an E3 ubiquitin ligase targeting NLRP3 and triggers host cell necrosis [49]. YopK is a particular virulence-associated factor that modulates the rate of injection of other Yops from within host cells [50] and also inhibits inflammasome activation [51]. It is important to highlight, as previously mentioned, that the function of several Yops has been studied only in $Y$. pseudotuberculosis or $Y$. enterocolitica, and remains to be investigated in $Y$. pestis.

Delivery of Yop effectors as well as cell invasion require adhesion of $Y$. pestis to host cells. Chromosomally encoded 
Ail outer-membrane protein contributes to cell attachment, Yop delivery, and serum resistance [52]. Another factor promoting Yop secretion is the Psa fimbriae (pH 6 antigen) that inhibit phagocytosis by macrophages and mediate Yersinia binding to epithelial cells by interacting with glycosphingolipids and phosphatidylcholine [53]. In contrast, the pFra/pMT1-encoded capsular antigen fraction 1 (F1) prevents bacterial uptake by inhibiting adhesion [54]. Subversion of host innate immunity also relies on abundant outer-membrane components, including the Braun lipoprotein Lpp [55] and the lipopolysaccharide, whose lipid A moiety is differentially acylated in a temperature-dependent manner by the acyltransferase MsbB (LpxM) [56]. The absence of the LpxL/HtrB acyltransferase in $Y$. pestis yields a tetra-acylated LPS, an antagonist for TLR4 receptors, which thus counteracts innate immunity [57]. The protease $\mathrm{Pla}$, encoded in the $9.5-\mathrm{kb}$ plasmid $\mathrm{pPla} / \mathrm{pPCP} 1$, is another outer-membrane protein playing a key role in $Y$. pestis virulence through its adhesive, invasive, fibrinolytic, and coagulase properties. It has been shown to cleave multiple host cell substrates in vitro and/or in vivo, including plasminogen, alpha-2-antiplasmin, plasminogen activator inhibitor-1, urokinase plasminogen activator, C3 complement component, Fas ligand FasL, and the dual peroxidase/ phospholipase peroxiredoxin [58, 59]. Pla, Ail, and F1 have been detected in outer-membrane vesicles, which may contribute to pathogenesis by dispersion and delivery of virulence factors [60].

Recently, novel virulence factors have been identified using a "per-pool" mutant screening method [61], as well as transposon sequencing (Tn-seq) and signature-tagged mutagenesis (STM) approaches [62, 63]. By investigating a library of $Y$. pestis mutants, the gene ympt1.66c (encoding a putative helicase) was identified as required for bacterial intracellular survival during the early stages of bubonic plague [61]. Besides known virulence genes, genome-wide fitness profiling led to the identification of more than 30 genes involved in nutrient acquisition and metabolism, which were necessary for infection, including the branchedchain amino-acid importer BrnQ [62]. Using STM and a murine model of pneumonic plague, a total of 118 mutants were found to have a lower capacity to colonize the spleen [63]. A secondary screen revealed that 20 out of the 118 individual mutants displayed attenuated virulence similarly in a murine model of bubonic plague: mutations were present not only in Pla but also in proteins of unknown function that require further characterization. Moreover, the study uncovered roles in $Y$. pestis pathogenesis for the type 6 secretion system (T6SS) component VasK and the ribose transport system ATP-binding protein RbsA [63]. Additional T6SS components have been shown to play an important role in macrophage cytotoxicity, resistance to phagocytosis, and in a murine model of pneumonic plague
[64]. In the same study, four new factors identified by STM were confirmed to contribute to virulence in mice, namely the general secretion pathway protein $\mathrm{E}$ of the type 2 secretion system GspE, the $\beta \gamma$ crystallin superfamily protein Ypo2884, the cytochrome $o$ oxidase CyoABCDE, and the multifunctional Tol-Pal system proteins Ypo11191120 [64]. Further investigation will be required to understand their role in pathogenesis.

A critical property of bacterial pathogens is their capacity to overcome nutritional immunity, i.e., host sequestration of essential metals such as iron and zinc [65], a mechanism which can protect against plague [66]. To acquire iron, $Y$. pestis secretes the siderophore yersiniabactin (Ybt), which has been shown to be essential for bubonic and pneumonic plague [67]. In addition, the Yfe and Feo metal transporters play a role in bubonic plague [68]. Interestingly, the Ybt biosynthetic machinery is also necessary for zinc uptake by $Y$. pestis. Together with Ybt, the ABC transporter ZnuABC and $\mathrm{YbtX}$, a member of the major facilitator superfamily, contribute to infection in murine models of plague [69-71]. YbtX was among the five new virulence factors involved in the development of pneumonic plague in mice that were identified using in vivo transcriptional profiling of $Y$. pestis [70]. The role of the other four factors, the phage-shock system PspABC, the protein of unknown function YPO0862, the putative esterase YPO1501, and the nitrite transporter NirC, remains to be defined.

\section{Yersinia pestis and subversion of host innate immunity}

One of the most surprising features of $Y$. pestis infection, either through a flea bite or through contamination via respiratory droplets, is the brutal transition from an absence of immune response and clinical symptoms, to a bursting inflammation and fatal sepsis with abundant bacteria in the body. This lag period has been termed "pre-inflammatory phase" and benefits $Y$. pestis, which migrates toward lymph nodes (bubonic plague) or lungs (pneumonic plague) to multiply silently. This immune evasion is exerted by several mechanisms that include the T3SS-mediated neutralization of immune cells (see the previous section), the absence of detectable pathogen-associated molecular patterns (PAMPs [57]), and modulation of host innate immune cell interactions (detailed below).

Neutrophils are a very early line of innate defense and inflammation at infection sites. It was commonly accepted that $Y$. pestis is eliminated effectively when phagocytosed by neutrophils, but survives and replicates when phagocytosed by macrophages. It has now been shown that $Y$. pestis grown at flea temperature (close to that of the host skin) at which the T3SS is not yet upregulated, can survive and 
replicate within human neutrophils [72]. Y. pestis can also transit from this first niche to a second one when macrophages phagocytose infected neutrophils in a cleaning process named efferocytosis [73]. Within macrophages, $Y$. pestis can survive in autophagosomes [74], and it has recently been shown that $Y$. pestis is also capable of inhibiting phagosomal maturation by perturbing the host endosomal recycling pathway, allowing bacterial intracellular replication [75, 76]. Efferocytosis is accompanied by secretion of IL-1RA [73], a cytokine exerting antiinflammatory effects by blocking IL-1R1 signaling: this strategy would allow $Y$. pestis to reduce innate immunity mechanisms and multiply, meanwhile upregulating its T3SS. Then, in target organs, $Y$. pestis would preferentially inject Yops in neutrophils by specifically recognizing their surface complement receptor 3 [77] and resists neutrophils toxic effectors through the activity of the lysozyme inhibitor Ivy [78] and the two-component regulatory system OmpREnvZ [79].

How $Y$. pestis disseminates from skin flea injection sites to lymph nodes was unknown and it was suspected that phagocytes (i.e., macrophages, dendritic cells, or neutrophils) could carry the bacteria. This scenario has been challenged by recent observations in murine models of infection, suggesting that the $Y$. pestis spread from the skin is very rapidly achieved [80] in the absence of interactions with host cells [81], suggesting therefore that bacterial transport to the draining lymph nodes can be driven solely by lymph flow [82]. However, an intracellular carriage by dendritic cells and monocytes motivated principally by sphingosine-1 phosphate (S1P)-driven chemotaxis toward lymph nodes was also reported, that probably occurs more slowly [83].

Within the infected lymph nodes, several pathways of cell death have been proposed to be activated by $Y$. pestis [84]. Applying murine $Y$. pseudotuberculosis infection models, it has been suggested that the T3SS effector YopJ induces macrophage apoptosis [85], a noninflammatory mechanism required for bacterial systemic infection [86]. However, in a bubonic rat infection model, YopJ-induced apoptosis was not required for $Y$. pestis virulence [87]. Necroptosis has been proposed to be required for $Y$. pestis dissemination from lymph nodes during the preinflammatory phase: cell membrane rupture leads to bacterial release and subsequent capture by phagocytes chemotactically attracted by S1P [88]. Bacterial intracellular carriage by dendritic cells and monocytes would then mediate $Y$. pestis node-to-node trafficking [83]. Of note, it has been reported that $Y$. pseudotuberculosis redirects apoptosis to caspase-1-dependent inflammatory pyroptosis in pre-activated cells [89], and $Y$. pestis-induced pyroptosis results from YopJ blockade of kinase TAK1, which activates caspase- 8 and pore-forming gasdermin D [90].
Paradoxically, other Yops (YopM and YopK) oppose to pyroptosis by preventing inflammasome and caspase-1 activation $[47,51]$. How $Y$. pestis could induce necroptosis also requires clarification, as caspase- 8 cleavage, the signal for $Y$. pestis-induced cell death [91], has been reported to inhibit necroptosis [92]. Interestingly, caspase-8 also controls antibacterial immunity and Toll-like receptorinduced cytokine production, and mice lacking caspase-8 are highly susceptible to Yersinia infection [93].

Despite being caused by the same pathogen, pneumonic plague differs from bubonic plague by the mode of infection (aerosols versus fleas), the target tissue (lungs versus skin/ lymph nodes), and ultimately pathophysiology and lethality. The pre-inflammatory phase during pneumonic plague generates a permissive environment that allows $Y$. pestis growth [94]. Resident alveolar macrophages are targeted early in infection, followed by preferential targeting of neutrophils in the later stages [95]. Inflammasomedependent IL-1 $1 /$ IL-18 release occurs early after bacteria enter the lung, but fails to cause inflammation due to the simultaneous release of anti-inflammatory IL-RA blocking IL-1 receptors [96]. Therefore, and interestingly, IL-1RA thus seems to play a key role in establishing the preinflammatory phase of both bubonic and pneumonic forms of plague $[73,96]$. In the latter, during the pro-inflammatory stage associated with clinical symptoms, neutrophils attracted to lungs are responsible for the pneumonia and necrosis destroying the lungs [95]. In this context, the T3SS effector YopK is a critical modulator of macrophage apoptosis and promotes progression of pneumonic plague toward the inflammatory stage [97]. An important distinction between bubonic and pneumonic plague is the temperature of the environment in which the bacteria grew prior to transmission: $Y$. pestis infecting lungs via aerosols that initially grew at $37^{\circ} \mathrm{C}$ in the contaminating patient's lungs [98], have therefore an upregulated T3SS and are thus more able than bacteria grown below $30^{\circ} \mathrm{C}$ in fleas to kill host cells. It has been shown that YopM inhibits the death of neutrophils in the center of lung lesions, preventing the release of their bactericidal and inflammatory content [99]. In consequence, as in the bubo, a delay in cell death contributes to the lag before the pro-inflammatory phase.

The existence of a pre-inflammatory phase during plague suggested that intervention to trigger a faster response of innate immunity could possibly counteract infection, as first indicated by an earlier report that inflammation resulting from a strong lipopolysaccharide response overcame $Y$. pestis virulence [57]. Two recent studies further show that specifically fostering the action of neutrophils or macrophages, respectively, at the very onset of the disease can control $Y$. pestis infection process. In mouse lungs, a cytokine-induced recruitment of neutrophils reduced bacterial counts and improved survival from pneumonic plague 
[100]. In a mouse bubonic plague model, transferring M1polarized macrophages also enhanced survival [101].

Innate immunity mechanisms are amplified when adaptive immunity is effective, such as after vaccination (see next section), and contribute to protection. In that regard, several recent observations point to a role for IL-17 in both wings of this response. During the innate response, IL-17 acts by inducing production of antimicrobial peptides and attracting neutrophils [102], as well as by activating macrophages to produce IFN $\gamma$ [103]. IL-17-producing T lymphocytes (Th17 cells) have been reported to be essential to cure pneumonic plague [104]. Surprisingly, a mechanism of Th17 induction may be injection of Yops into naive T cells, as observed with $Y$. pseudotuberculosis [105]. In agreement, vaccination using a live attenuated $Y$. pestis NIIEG strain induces a Th17 polarization in humans [106]. Moreover, Th17 cells may develop in parallel to Th1 ones, as was observed with a live $Y$. pseudotuberculosis oral plague vaccine [107]. Therefore, IL-17 appears important against plague, and how it is limited during the pre-inflammatory phase needs to be determined (Fig. 3).

\section{Vaccination against plague}

Despite considerable progress in prevention and cure, natural foci still exist in Africa, Asia, and America, and plague is endemic in more than 25 countries worldwide, which would benefit from vaccination. No new vaccine has recently been licensed in Europe or in the United States to replace the killed whole-cell $Y$. pestis formerly produced in the United States and Australia, which was discontinued because of its short-lasting protection and low efficiency. The live $Y$. pestis EV vaccine previously used with benefit in Madagascar, and still used in Asia and Russia, was never licensed in occidental countries. Most current efforts are focused on vaccines against pneumonic plague, considering $Y$. pestis as a potential biowarfare agent. The most advanced candidates are molecular vaccines developed by the United States, the United Kingdom, and China governmental agencies, and are patented but not yet licensed. They combine $Y$. pestis $\mathrm{F} 1$ and $\mathrm{V}$ antigens and are called $\mathrm{rF} 1-\mathrm{V}$, RypVax, and SV1, respectively. F1 is the main protein component of the pseudocapsule, and is a dispensable virulence factor. The $\mathrm{V}$ antigen (LcrV) is an essential part of the T3SS. Two doses of these F1/V vaccines provide $100 \%$ protection to mice against bubonic and pneumonic plague [108-111]. However, when F1-V was tested in nonhuman primates, Cynomolgus macaques could be protected against aerosolized $Y$. pestis, but not African green monkeys [112]. Therefore, it is not yet clear whether F1-V would reliably provide protection to humans. Because $\mathrm{rF1-V}$ and SV1 have completed phase I and II trials, WHO recently gathered experts to define principles on how to build phase III plague vaccine efficacy trials in endemic countries [113]. $\mathrm{rF} 1-\mathrm{V}$ is announced for 2021 for use by the US army and licensure in the United States can be obtained following FDA's "Animal rule", a procedure which applies when traditional efficacy trials in humans are unethical or impractical [114].

Several other vaccine candidates have been proposed. Many $Y$. pestis strains attenuated by genetic engineering are immunogenic and confer protection, but none was brought to the clinical evaluation phases. Another molecular vaccine, patented by the University of Chicago and called V10, is composed of a shorter $\mathrm{V}$ antigen only, and provided $100 \%$ protection against bubonic and pneumonic plague to mice and Cynomolgus macaques [115]. Live vector vaccines producing $\mathrm{F} 1$ and $\mathrm{V}$ have also been developed, using the modified Vaccinia virus (strain Ankara: MVA) or attenuated Salmonella as a vector. However, these vaccines did not progress to clinical trials. A live Y. pseudotuberculosis may also be a valuable vaccine against plague [116, 117]. We developed a live attenuated $Y$. pseudotuberculosis strain producing the F1 pseudocapsule, named VTnF1 [107]. Because a single oral dose provided protection of mice against bubonic and pneumonic forms caused by high doses of $Y$. pestis, VTnF1 appears as a very promising plague vaccine candidate.

\section{Plague diagnostics: lessons from the 2017 pneumonic plague outbreak in Madagascar}

As previously mentioned, pneumonic plague is transmitted from person to person through respiratory droplets. After an incubation period of 24-96 h, the disease progresses rapidly and is nearly always fatal in a few days in the absence of an early antimicrobial treatment. From August to November 2017, Madagascar experienced an unprecedentedly large pneumonic plague outbreak with multiple foci, including two main urban areas: Antananarivo, the capital, and Toamasina, the main seaport [10]. A total of 2414 suspected cases were reported. Spread of pneumonic plague was of great concern as its propagation is favored by the closeness of people, especially in the densely populated cities. Health authorities urgently had to organize the screening of the suspected patients, the collection of samples for biological diagnosis, the prompt treatment of patients, and the followup of the contacts. In the context of this outbreak, light was brought toward the specific problems associated with the diagnosis of pneumonic plague.

Screening of the suspected patients was based on epidemiological and clinical criteria, as described in the case definition provided by the World Health Organization (WHO) [118] and biological samples were collected at the points of care. Biological diagnosis of pneumonic plague 

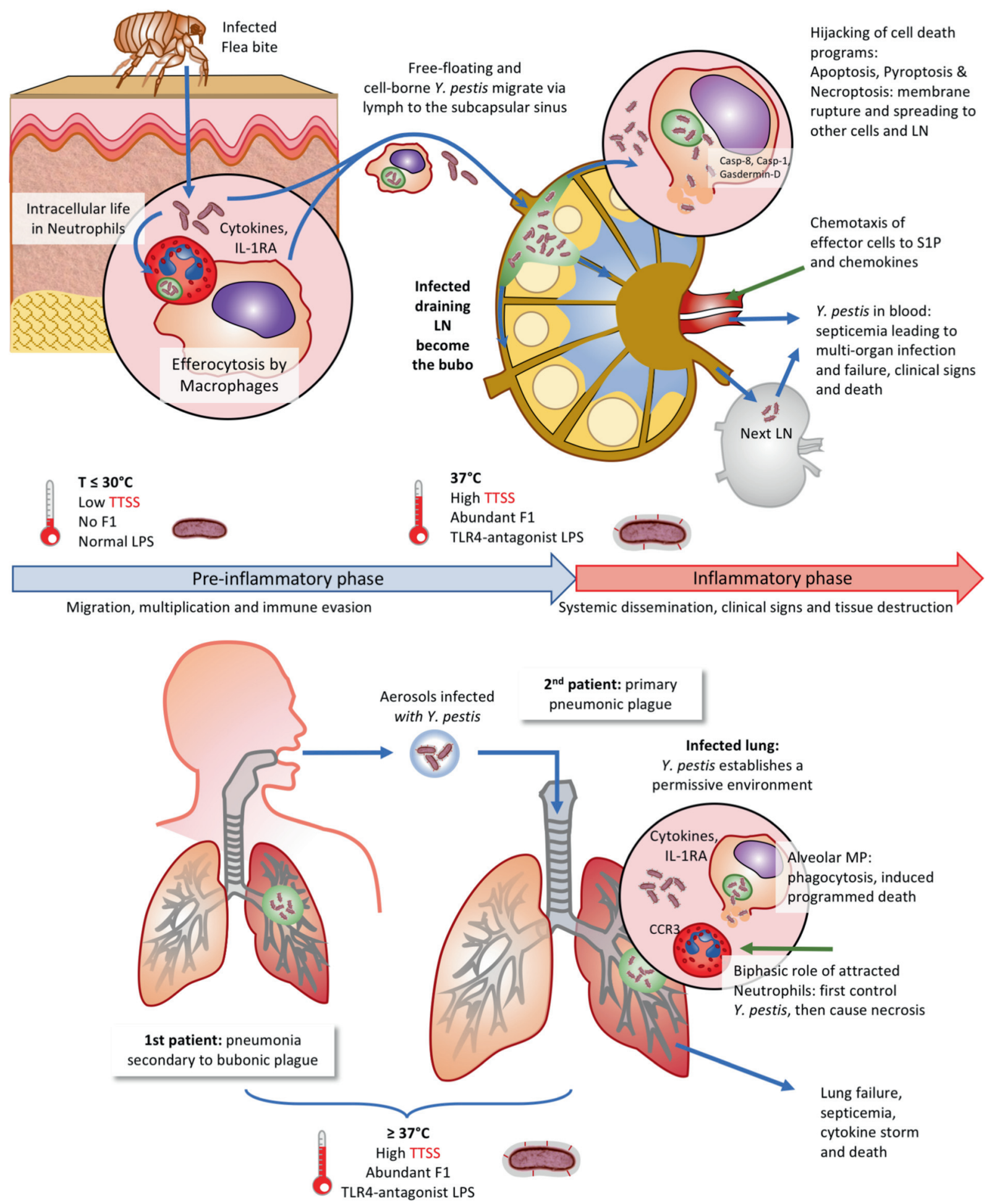

Fig. 3 Innate immunity subversion by Yersinia pestis. Schematic representation of $Y$. pestis transmission and migration in the human body during bubonic (upper panel) and pneumonic plague (lower panel). The effect of temperature of origin and its effects on the

bacterium are indicated at various steps. A focus is given on innate immunity host cells encountered by the pathogen and involved in immune evasion mechanisms described in the text, which are shown as zoomed areas

highly relies on the quality of the sample: since pneumonic plague is a lower respiratory tract infection, deep respiratory secretions are required for biological tests, not saliva or spit.

However, during an outbreak, the aim is to diagnose the disease during the invasion phase before the onset of severe symptoms. Thus, producing good-quality sputum is often 


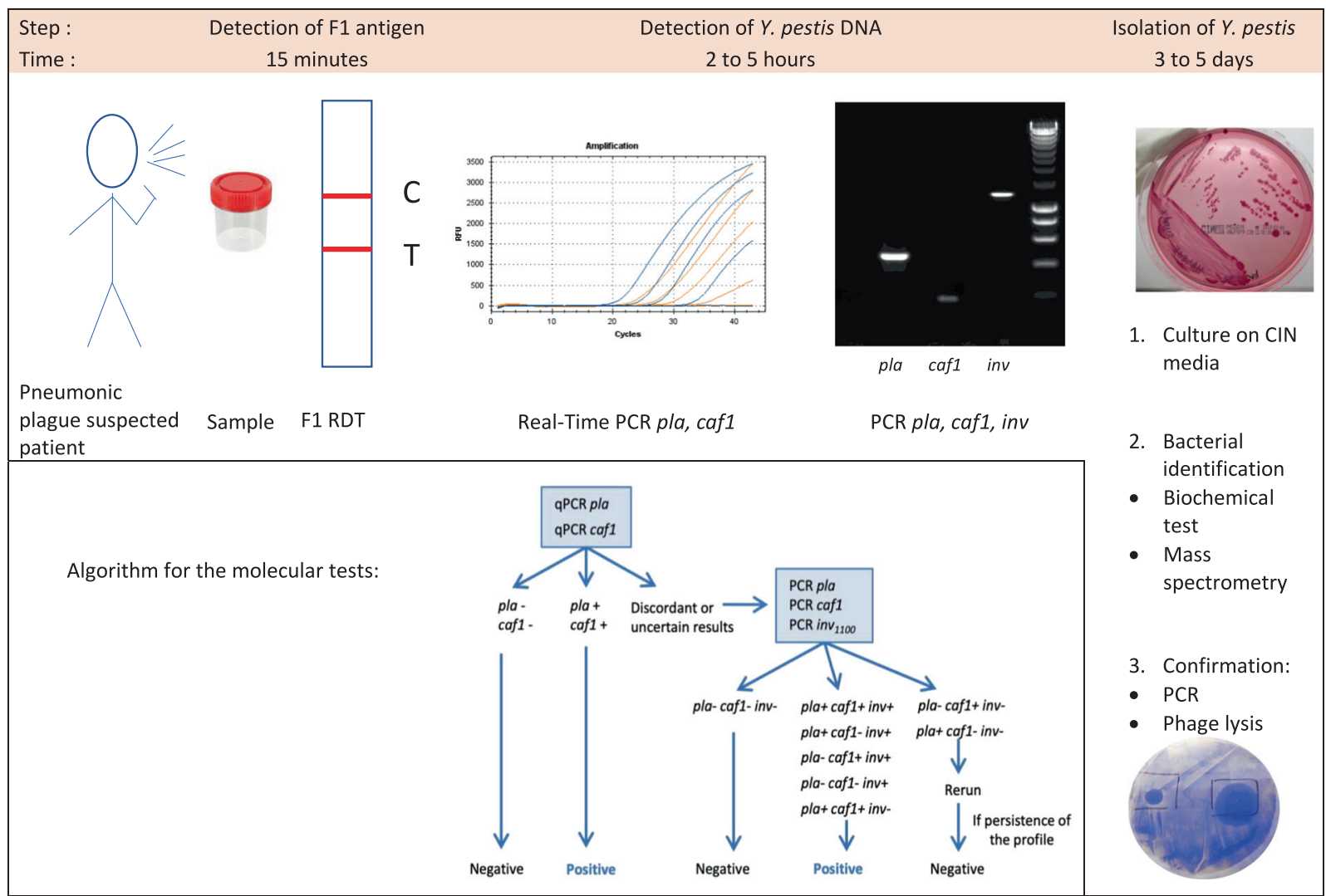

Fig. 4 Plague diagnostics: from presumption to confirmation. Upon plague suspicion, according to epidemiological and clinical criteria, collected samples (sputum, expectoration) can be analyzed for the detection of the $Y$. pestis capsular antigen $\mathrm{F} 1$ using the rapid diagnostic test (RDT: the $\mathrm{C}$ band is a migration control, and the $\mathrm{T}$ band reveals the presence of F1). Confirmation is performed through detection of $Y$. pestis DNA using real-time PCR targeting pla and cafl, and in the case of discordant or uncertain results, a PCR targeting pla, cafl, and inv is performed. Isolation of $Y$. pestis remains the gold standard in biological diagnostic tests: culture on selective CIN media is followed by bacterial identification using biochemical tests or mass spectrometry, confirmation using PCR, and phage lysis. Boxed area: algorithm for molecular tests using qPCR and PCR (reprinted from ref. [135])

Molecular biology tests have been developed in order to reduce the delay and increase the sensitivity of diagnostics (Fig. 4). Conventional polymerase chain reactions (PCR) targeting the pla, cafl, inv, and yopM genes [121, 122] reduce the delay of diagnostics to 3-4 h, while real-time PCR can be performed in only $2 \mathrm{~h}$. The pla gene is located on the pPla/pPCP1 plasmid, which is present in 150-200 copies per bacterium [123], resulting in a high sensitivity. A real-time PCR targeting pla in the sputum [124] displays a sensitivity of $100 \mathrm{cfu} / \mathrm{ml}$ in spiked sputum. However, pla may also be found in other Enterobacteriaceae such as Citrobacter koseri and Escherichia coli [125] and these bacteria may be present in the sputum. Therefore, the sputum must be tested by multiplex real-time PCR, targeting additional genes. The cafl gene is located on the pFra/ pMT1 plasmid, which is considered specific to $Y$. pestis, but it is present in only about two copies per bacterium [123]. A multiplex real-time PCR on pla and cafl has been described [126] but it was tested only in patients with suspected bubonic plague (not on sputum). The yopM gene, located on 
the Yersinia virulence plasmid $\mathrm{pYV} / \mathrm{pCD} 1$, is present in about four copies per bacterium, but pYV may also be found in $Y$. pseudotuberculosis and pathogenic $Y$. enterocolitica strains. The inv gene is a chromosomal gene present in $Y$. pestis and $Y$. pseudotuberculosis; an insertion in $Y$. pestis made it larger [127] and a conventional PCR may distinguish it by the amplicon sizes produced in $Y$. pseudotuberculosis (400 bp) compared with $Y$. pestis (1100 bp). During the 2017 pneumonic plague outbreak in Madagascar, the strategy chosen to detect $Y$. pestis DNA was first to test the samples by a multiplex real-time PCR targeting pla and cafl, and to confirm the uncertain cases by a conventional PCR targeting pla, cafl, inv $v_{1100 b p}$, and yopM. It is worth mentioning that the chromosomal gene ypo2088 is specific to $Y$. pestis and spiked expectorations have been successfully tested by real-time PCR targeting this gene [128]. Molecular biology tests are usually performed in hospitals and research institutions; however, portable realtime PCR instruments are being developed and could be helpful in remote plague endemic areas [129]. Assays relying on the loop-mediated isothermal amplification (LAMP) technology have also been developed [130], but they still remain to be evaluated on sputum.

Among the biological diagnostic tests, microbial isolation of $Y$. pestis remains the gold standard. Although $Y$. pestis can grow on usual culture media, the use of a selective agar supplemented in cefsulodin-irgasan-novobiocin (CIN) favors the isolation of the bacterium in polymicrobial samples such as sputum. WHO recommendations are to rinse the mouth out with water prior to sample collection in order to reduce the contaminations by the oral flora [131]. After 2- or 3-day incubation at $28^{\circ} \mathrm{C}$, suspected colonies on CIN agar may be identified by biochemical tests, PCR, and Y. pestis-specific phage lysis. Automated identification systems are more and more often used in the laboratories: they are fast and can efficiently identify a large variety of bacteria; however, misidentifications of $Y$. pestis have been reported [132]; therefore, a reference laboratory must always confirm the taxonomic assignation.

\section{Concluding remarks}

Due to its exceptional virulence, its multiple modes of transmission and pathogenesis, its outstanding skills to escape host molecular and cellular immunity mechanisms, and the indelible mark it has left on human societies in the past, Y. pestis is a remarkable model to study infection and the evolution of bacterial pathogenicity. The recent improvement in high-end technologies, allowing wholegenome sequencing and more resolution in vitro as well as in vivo microscopy, has directly benefitted the understanding of various aspects of plague, including bacterial phylogeny, pandemics history, pathogenesis mechanisms, and subversion of immune responses.

However, several aspects of plague natural history are still incompletely understood. The ecology of $Y$. pestis in the environment remains to be fully explored, as novel potential reservoirs are discovered [133, 134]. Some molecular mechanisms of virulence of $Y$. pestis have been inferred from comparisons with other pathogenic Yersiniae, including the enteric pathogens $Y$. pseudotuberculosis and $Y$. enterocolitica, which might bias our understanding of plague. More studies using fully virulent $Y$. pestis strains are required to completely grasp the physiopathology of the disease. The bacillus discovered 125 years ago by Alexandre Yersin has still a lot of secrets to reveal.

Acknowledgements We would like to thank colleagues from the Institut Pasteur and particularly from the Yersinia Research Unit for critical reading of this paper. Due to space limitations, we apologize to those authors whose work was not cited in this article.

Funding We acknowledge funding from Institut Pasteur, Direction Générale de l'Armement, l'Agence Innovation Défense, l'Agence Nationale de la Recherche (ANR10-LBX-62 IBEID, ANR18-ASTR004-01), and Université Paris-Diderot.

\section{Compliance with ethical standards}

Conflict of interest The authors declare that they have no conflict of interest.

Publisher's note: Springer Nature remains neutral with regard to jurisdictional claims in published maps and institutional affiliations.

Open Access This article is licensed under a Creative Commons Attribution 4.0 International License, which permits use, sharing, adaptation, distribution and reproduction in any medium or format, as long as you give appropriate credit to the original author(s) and the source, provide a link to the Creative Commons license, and indicate if changes were made. The images or other third party material in this article are included in the article's Creative Commons license, unless indicated otherwise in a credit line to the material. If material is not included in the article's Creative Commons license and your intended use is not permitted by statutory regulation or exceeds the permitted use, you will need to obtain permission directly from the copyright holder. To view a copy of this license, visit http://creativecommons. org/licenses/by/4.0/.

\section{References}

1. Stenseth NC, Atshabar BB, Begon M, Belmain SR, Bertherat E, Carniel E, et al. Plague: past, present, and future. PLoS Med. 2008;5:e3.

2. Perry RD, Fetherston JD. Yersinia pestis-etiologic agent of plague. Clin Microbiol Rev. 1997;10:35-66.

3. Yersin A. La peste bubonique a Hong-Kong. Ann Inst Pasteur (Paris). 1894;8:662-7.

4. Vogler AJ, Chan F, Nottingham R, Andersen G, Drees K, Beckstrom-Sternberg SM, et al. A decade of plague in 
mahajanga, madagascar: insights into the global maritime spread of pandemic plague. mBio. 2013;4:e00623-12-e00623-12.

5. Bertherat E. Plague around the world, 2010-2015. Wkly Epidemiol Rec. 2016;91:89-104.

6. Respicio-Kingry LB, Yockey BM, Acayo S, Kaggwa J, Apangu $\mathrm{T}$, Kugeler KJ, et al. Two distinct Yersinia pestis populations causing plague among humans in the West Nile region of Uganda. PLoS Negl Trop Dis. 2016;10:e0004360.

7. Shi L, Yang G, Zhang Z, Xia L, Liang Y, Tan H, et al. Reemergence of human plague in Yunnan, China in 2016. PLoS ONE. 2018;13:e0198067.

8. Abedi AA, Shako J-C, Gaudart J, Sudre B, Ilunga BK, Shamamba SKB, et al. Ecologic features of plague outbreak areas, Democratic Republic of the Congo, 2004-2014. Emerg Infect Dis. 2018;24:210-20.

9. Andrianaivoarimanana V, Piola P, Wagner DM, Rakotomanana F, Maheriniaina V, Andrianalimanana S, et al. Trends of human plague, madagascar, 1998-2016. Emerg Infect Dis. 2019;25:220-8.

10. Randremanana R, Andrianaivoarimanana V, Nikolai B, Ramasindrazana B, Paireau J, ten Bosch QA, et al. Epidemiological characteristics of urban plague epidemic in Madagascar, AugustNovember 2017: an outbreak report. Lancet Infect Dis. (in press).

11. McNally A, Thomson NR, Reuter S, Wren BW. 'Add, stir and reduce': Yersinia spp. as model bacteria for pathogen evolution. Nat Rev Micro. 2016;14:177-90.

12. Hinnebusch BJ, Jarrett CO, Bland DM. 'Fleaing' the plague: adaptations of Yersinia pestisto Its insect vector that lead to transmission. Annu Rev Microbiol. 2017;71:215-32.

13. Valtueña AA, Mittnik A, Key FM, Haak W, Allmäe R, Belinskij $\mathrm{A}$, et al. The stone age plague and its persistence in Eurasia. Curr Biol. 2017;27:3683. e8

14. Rascovan N, Sjögren K-G, Kristiansen K, Nielsen R, Willerslev E, Desnues C, et al. Emergence and Spread of Basal Lineages of Yersinia pestis during the Neolithic Decline. Cell. 2019;176:295-305.

15. Rasmussen S, Allentoft ME, Nielsen K, Orlando L, Sikora M, Sjögren K-G, et al. Early divergent strains of Yersinia pestis in Eurasia 5,000 years ago. Cell. 2015;163:571-82.

16. Spyrou MA, Tukhbatova RI, Wang C-C, Valtueña AA, Lankapalli AK, Kondrashin VV, et al. Analysis of 3800-year-old Yersinia pestis genomes suggests Bronze Age origin for bubonic plague. Nat Commun. 2018;9:1-10.

17. Sun Y-C, Jarrett CO, Bosio CF, Hinnebusch BJ. Retracing the evolutionary path that ledto flea-borne transmission of Yersinia pestis. Cell Host Microbe. 2014;15:578-86.

18. Cui Y, Yu C, Yan Y, Li D, Li Y, Jombart T, et al. Historical variations in mutation rate in an epidemic pathogen, Yersinia pestis. Proc Natl Acad Sci USA. 2013;110:577-82.

19. Chouikha I, Hinnebusch BJ. Silencing urease: A key evolutionary step that facilitated the adaptation of Yersinia pestisto the flea-borne transmission route. Proc Natl Acad Sci USA. 2014;111:18709-14.

20. Zimbler DL, Schroeder JA, Eddy JL, Lathem WW. Early emergence of Yersinia pestis as a severe respiratory pathogen. Nature. Communications. 2015;6:1-10.

21. Harbeck M, Seifert L, Hänsch S, Wagner DM, Birdsell D, Parise $\mathrm{KL}$, et al. Yersinia pestis DNA from Skeletal Remains from the 6th Century AD Reveals Insights into Justinianic Plague. PLoS Pathog. 2013;9:e1003349.

22. Wagner DM, Klunk J, Harbeck M, Devault A, Waglechner N, Sahl JW, et al. Yersinia pestis and the plague of Justinian 541543 AD: a genomic analysis. Lancet Infect Dis. 2014;14:319-26.

23. Bos KI, Schuenemann VJ, Golding GB, Burbano HA, Waglechner N, Coombes BK, et al. A draft genome of Yersinia pestis from victims of the Black Death. Nature. 2011;478:506-10.
24. Haensch S, Bianucci R, Signoli M, Rajerison M, Schultz M, Kacki S, et al. Distinct clones of Yersinia pestis caused the black death. PLoS Pathog. 2010;6:e1001134.

25. Kutyrev VV, Eroshenko GA, Motin VL, Nosov NY, Krasnov JM, Kukleva LM, et al. Phyloogeny and classification of Yersinia pestis through the lens of strains from the plague foci of commonwealth of independent states. Front Microbiol. 2018;9:14043.

26. Namouchi A, Guellil M, Kersten O, Hänsch S, Ottoni C, Schmid $\mathrm{BV}$, et al. Integrative approach using Yersinia pestisgenomes to revisit the historical landscape of plague during the Medieval Period. Proc Natl Acad Sci USA. 2018;918:201812865.

27. Schmid BV, Büntgen U, Easterday WR, Ginzler C, Walløe L, Bramanti B, et al. Climate-driven introduction of the Black Death and successive plague reintroductions into Europe. Proc Natl Acad Sci USA. 2015;112:3020-5.

28. Yue RPH, Lee HF, Wu CYH. Trade routes and plaguetransmission in pre-industrial Europe. Sci Rep.2017;7:1-10.

29. Bos KI, Herbig A, Sahl J, Waglechner N, Fourment M, Forrest $\mathrm{SA}$, et al. Eighteenth century Yersinia pestis genomes reveal the long-term persistence of an historical plague focus. eLife. 2016;5:e12994.

30. Spyrou MA, Tukhbatova RI, Feldman M, Drath J, Kacki S, de Heredia JB, et al. Historical Y. pestis genomes reveal the European Black Death as the source of ancient and modern plague pandemics. Cell Host Microbe. 2016;19:874-81.

31. Seifert L, Wiechmann I, Harbeck M, Thomas A, Grupe G, Projahn M, et al. Genotyping Yersinia pestis in historical plague: evidence for long-term persistence of Y. pestis in Europe from the 14th to the 17th century. PLoS ONE. 2016;11:e0145194.

32. Dean KR, Krauer F, Walløe L, Lingjærde OC, Bramanti B, Stenseth NC, et al. Human ectoparasites and the spread of plague in Europe during the second pandemic. Proc Natl Acad Sci USA. 2018;115:1304-9.

33. Morelli G, Song Y, Mazzoni CJ, Eppinger M, Roumagnac P, Wagner DM, et al. Yersinia pestis. Nat Genet. 2010;42:1140-3.

34. Riehm JM, Projahn M, Vogler AJ, Rajerison M, Andersen G, Hall CM, et al. Diverse genotypes of Yersinia pestis caused plague in Madagascar in 2007. PLoS Negl Trop Dis. 2015;9: e0003844.

35. Vogler AJ, Andrianaivoarimanana V, Telfer S, Hall CM, Sahl JW, Hepp CM, et al. Temporal phylogeography of Yersinia pestis in Madagascar: insights into the long-term maintenance of plague. PLoS Negl Trop Dis. 2017;11:e0005887.

36. Atkinson S, Williams P. Yersinia virulence factors-a sophisticated arsenal for combating host defences. F1000Research. 2016;5:1370-10.

37. Cornelis GR. The Yersinia Ysc-Yop 'Type III' weaponry. Nat Rev Mol Cell Biol. 2002;3:742-54.

38. Diepold A, Sezgin E, Huseyin M, Mortimer T, Eggeling C, Armitage JP. A dynamic and adaptive network of cytosolic interactions governs protein export by the T3SS injectisome. Nat Commun.2017;8:15940.

39. Nauth T, Huschka F, Schweizer M, Bosse JB, Diepold A, Failla $\mathrm{AV}$, et al. Visualization of translocons in Yersinia type III protein secretion machines during host cell infection. PLOS Pathog. 2018;14(12):e1007527.

40. Trosky JE, Liverman ADB, Orth K. Yersinia outer proteins: Yops. Cell Microbiol. 2008;10:557-65.

41. Persson C, Carballeira N, Wolf-Watz H, Fallman M. The PTPase YopH inhibits uptake of Yersinia, tyrosine phosphorylation of p130Cas and FAK, and the associated accumulation of these proteins in peripheral focal adhesions. EMBO J. 1997;16:230718.

42. Evdokimov AG, Tropea JE, Routzahn KM, Waugh DS. Crystal structure of the Yersinia pestis GTPase activator YopE. Protein Sci. 2009;11:401-8. 
43. Shao F, Merritt PM, Bao Z, Innes RW, Dixon JE. A Yersinia effector and a Pseudomonas avirulence protein define a family of cysteine proteases functioning in bacterial pathogenesis. Cell. 2002;109:575-88.

44. Orth K, Xu Z, Mudgett MB, Bao ZQ, Palmer LE, Bliska JB, et al. Disruption of signaling by Yersinia effector YopJ, a ubiquitin-like protein protease. Science. 2000;290:1594-7.

45. Mukherjee S, Keitany G, Li Y, Wang Y, Ball HL, Goldsmith EJ, et al. Yersinia YopJ acetylates and inhibits kinase activation by blocking phosphorylation. Science. 2006;312:1211-4.

46. Prehna G, Ivanov MI, Bliska JB, Stebbins CE. Yersinia virulence depends on mimicry of host rho-family nucleotide dissociation inhibitors. Cell. 2006;126:869-80.

47. LaRock CN, Cookson BT. The Yersinia virulence effector YopM brinds caspase- 1 to arrest inflammasome assembly and processing. Cell Host Microbe. 2012;12:799-805.

48. Berneking L, Schnapp M, Rumm A, Trasak C, Ruckdeschel K, Alawi M, et al. Immunosuppressive Yersinia Effector YopM Binds DEAD Box Helicase DDX3 to Control Ribosomal S6 Kinase in the Nucleus of Host Cells. PLOS Pathog. 2016;12(6): e1005660.

49. Wei C, Wang Y, Du Z, Guan K, Cao Y, Yang H, et al. The Yersinia Type III secretion effector YopM Is an E3 ubiquitin ligase that induced necrotic cell death by targeting NLRP3. Cell Death Dis. 2016;7:e2519.

50. Dewoody R, Merritt PM, Houppert AS, Marketon MM. YopK regulates the Yersinia pestis type III secretion system from within host cells. Mol Microbiol. 2011;79:1445-61.

51. Brodsky IE, Palm NW, Sadanand S, Ryndak MB, Sutterwala FS, Flavell RA, et al. A Yersinia effector protein promotes virulence by preventing inflammasome recognition of the type III secretion system. Cell Host Microbe. 2010;7:376-87.

52. Thomson JJ, Plecha SC, Krukonis ES. Ail provides multiple mechanisms of serum resistance to Yersinia pestis. Mol Microbiol. 2019;111:82-95.

53. Bao R, Nair MKM, Tang W-K, Esser L, Sadhukhan A, Holland $\mathrm{RL}$, et al. Structural basis for the specific recognition of dual receptors by the homopolymeric $\mathrm{pH} 6$ antigen (Psa) fimbriae of Yersinia pestis. Proc Natl Acad Sci USA. 2013;110:1065-70.

54. Liu F, Chen H, Galvan EM, Lasaro MA, Schifferli DM. Effects of Psa and F1 on the Adhesive and invasive interactions of Yersinia pestis with human respiratory tract epithelial cells. Infect Immun. 2006;74:5636-44.

55. Sha J, Agar SL, Baze WB, Olano JP, Fadl AA, Erova TE, et al. Braun Lipoprotein (Lpp) Contributes to Virulence of Yersiniae: potential Role of Lpp in Inducing Bubonic and Pneumonic Plague. Infect Immun. 2008;76:1390-409.

56. Sha J, Kirtley ML, van Lier CJ, Wang S, Erova TE, Kozlova EV, et al. Deletion of the Braun lipoprotein-encoding gene and altering the function of lipopolysaccharide attenuate the plague bacterium. Infect Immun. 2013;81:815-28.

57. Montminy SW, Khan N, McGrath S, Walkowicz MJ, Sharp F, Conlon JE, et al. Virulence factors of Yersinia pestis are overcome by a strong lipopolysaccharide response. Nat Immunol. 2006;7:1066-73.

58. Lathem WW, Price PA, Miller VL, Goldman WE. A plasminogen-activating protease specifically controls the development of primary pneumonic plague. Science. 2007;315:50913.

59. Zimbler DL, Eddy JL, Schroeder JA, Lathem WW. Inactivation of peroxiredoxin 6 by the Pla protease of Yersinia pestis. Infect Immun. 2015;84:365-74.

60. Eddy JL, Gielda LM, Caulfield AJ, Rangel SM, Lathem WW. Production of outer membrane vesicles by the plague pathogen Yersinia pestis. PLoS ONE. 2014;9:e107002.
61. Pradel E, Lemaître N, Merchez M, Ricard I, Reboul A, Dewitte A, et al. New insights into how Yersinia pestis adapts to its mammalian host during bubonic plague. PLoS Pathog. 2014;10: e1004029.

62. Palace SG, Proulx MK, Lu S, Baker RE, Goguen JD. Genomewide mutant fitness profiling identifies nutritional requirements for optimal growth of Yersinia pestis in deep tissue. mBio. 2014;5:e01385-14-e01385-14.

63. Ponnusamy D, Fitts EC, Sha J, Erova TE, Kozlova EV, Kirtley ML, et al. High-throughput, signature-tagged mutagenic approach to identify novel virulence factors of Yersinia pestis CO92 in a mouse model of infection. Infect Immun. 2015;83:2065-81.

64. Andersson JA, Sha J, Erova TE, Fitts EC, Ponnusamy D, Kozlova EV, et al. Identification of new virulence factors and vaccine candidates for Yersinia pestis. Front Cell Infect Microbiol. 2017;7:3717.

65. Hood MI, Skaar EP. Nutritional immunity: transitionmetals at the pathogen-host interface. Nat Rev Micro. 2012;10:525-37.

66. Zauberman A, Vagima Y, Tidhar A, Aftalion M, Gur D, Rotem $\mathrm{S}$, et al. Host iron nutritional immunity induced by a live Yersinia pestis vaccine strain is associated with immediate protection against plague. Front Cell Infect Microbiol. 2017;7:183.

67. Fetherston JD, Kirillina O, Bobrov AG, Paulley JT, Perry RD. The yersiniabactin transport system is critical for the pathogenesis of bubonic and pneumonic plague. Infect Immun. 2010;78:2045-52.

68. Fetherston JD, Mier I, Truszczynska H, Perry RD. The Yfe and Feo transporters are involved in microaerobic growth and virulence of Yersinia pestis in bubonic plague. Infect Immun. 2012;80:3880-91.

69. Bobrov AG, Kirillina O, Fetherston JD, Miller MC, Burlison JA, Perry RD. The Yersinia pestissiderophore, yersiniabactin, and the ZnuABC system both contribute to zinc acquisition and the development of lethal septicaemic plague in mice. Mol Microbiol. 2014;93:759-75.

70. Pechous RD, Broberg CA, Stasulli NM, Miller VL, Goldman WE. In vivo transcriptional profiling of Yersinia pestis reveals a novel bacterial mediator of pulmonary inflammation. mBio. 2015;6:e02302-14.

71. Bobrov AG, Kirillina O, Fosso MY, Fetherston JD, Miller MC, VanCleave TT, et al. Metallomics. Metallomics. 2017;9:757-72.

72. Shannon JG, Hasenkrug AM, Dorward DW, Nair V, Carmody AB, Hinnebusch BJ. Yersinia pestis subverts the dermal neutrophil response in a mouse model of bubonic plague. mBio. 2013;4:e0170-13-e00170-13.

73. Spinner JL, Winfree S, Starr T, Shannon JG, Nair V, SteeleMortimer O, et al. Yersinia pestis survival and replication within human neutrophil phagosomes and uptake of infected neutrophils by macrophages. J Leukoc Biol. 2014;95:389-98.

74. Pujol C, Klein KA, Romanov GA, Palmer LE, Cirota C, Zhao Z, et al. Yersinia pestis can reside in autophagosomes and avoid xenophagy in murine macrophages by preventing vacuole acidification. Infect Immun. 2009;77:2251-61.

75. Connor MG, Pulsifer AR, Price CT, Abu Kwaik Y, Lawrenz MB. Yersinia pestis requires host Rab1b for survival in macrophages. PLoS Pathog. 2015;11:e1005241.

76. Connor MG, Pulsifer AR, Chung D, Rouchka EC, Ceresa BK, Lawrenz MB. Yersinia pestis targets the host endosome recycling pathway during the biogenesis of the Yersinia-containing vacuole to avoid killing by macrophages. mBio. 2018;9:e01800-17.

77. Merritt PM, Nero T, Bohman L, Felek S, Krukonis ES, Marketon MM. Yersinia pestistargets neutrophils via complement receptor 3. Cell Microbiol. 2014;17:666-87.

78. Derbise A, Pierre F, Merchez M, Pradel E, Laouami S, Ricard I, et al. Inheritance of the lysozyme inhibitor Ivy was an important 
evolutionary step by Yersinia pestis to avoid the host innate immune response. J Infect Dis. 2013;207:1535-43.

79. Reboul A, Lemaître N, Titecat M, Merchez M, Deloison G, Ricard I, et al. Yersinia pestis requires the 2-component regulatory system OmpR-EnvZ to resist innate immunity during the early and late stages of plague. J Infect Dis. 2014;210:1367-75.

80. Shannon JG, Bosio CF, Hinnebusch BJ. Dermal neutrophil, macrophage and dendritic cell responses to Yersinia pestis transmitted by fleas. PLoS Pathog. 2015;11:e1004734.

81. Gonzalez RJ, Lane MC, Wagner NJ, Weening EH, Miller VL. Dissemination of a highly virulent pathogen: tracking the early events that define infection. PLoS Pathog. 2015;11:e1004587.

82. Gonzalez RJ, Miller VL. A deadly path: bacterial spread during bubonic plague. Trends Microbiol. 2016;24:1-3.

83. St. John AL, Ang WXG, Huang M-N, Kunder CA, Chan EW, Gunn MD, et al. S1P-dependent trafficking of intracellular Yersinia pestis through lymph nodes establishes buboes and systemic infection. Immunity. 2014;41:440-50.

84. Chung LK, Bliska JB. Science direct Yersinia versus host immunity: how a pathogen evades or triggers a protective response. Curr Opin Microbiol. 2016;29:56-62.

85. Monack DM, Mecsas J, Ghori N, Falkow S. Yersinia signals macrophages to undergo apoptosis and YopJ is necessary for this cell death. Proc Natl Acad Sci USA. 1997;94:10385-90.

86. Monack DM, Mecsas J, Bouley D, Falkow S. Yersinia-induced apoptosis in vivo aids in the establishment of a systemic infection of mice. J Exp Med. 1998;188:2127-37.

87. Lemaître N, Sebbane F, Long D, Joseph Hinnebusch B. Yersinia pestis YopJ suppresses tumor necrosis factor alpha induction and contributes to apoptosis of immune cells in the lymph node but is not required for virulence in a rat model of bubonic plague. Infect Immun. 2006;74:5126-31.

88. Arifuzzaman M, Ang WXG, Choi HW, Nilles ML, St John AL, Abraham SN. Necroptosis of infiltrated macrophages drives Yersinia pestis dispersal within buboes. JCI Insight. 2018;3:35.

89. Bergsbaken T, Cookson BT. Macrophage activation redirects yersinia-infected host cell death from apoptosis to caspase-1dependent pyroptosis. PLoS Pathog. 2007;3:e161.

90. Orning P, Weng D, Starheim K, Ratner D, Best Z, Lee B, et al. Pathogen blockade of TAK1 triggers caspase-8-dependent cleavage of gasdermin D and cell death. Science. 2018;362:1064-9.

91. Weng D, Marty-Roix R, Ganesan S, Proulx MK, Vladimer GI, Kaiser WJ, et al. Caspase-8 and RIP kinases regulate bacteriainduced innate immune responses and cell death. Proc Natl Acad Sci USA. 2014;111:7391-6.

92. O'Donnell MA, Perez-Jimenez E, Oberst A, Ng A, Massoumi R, Xavier R, et al. Caspase 8 inhibits programmed necrosis by processing CYLD. Nat Cell Biol. 2011;13:1437-42.

93. Philip NH, DeLaney A, Peterson LW, Santos-Marrero M, Grier JT, Sun Y, et al. Activity of uncleaved caspase- 8 controls antibacterial immune defense and TLR-induced cytokine production independent of cell death. PLoS Pathog. 2016;12:e1005910.

94. Price PA, Jin J, Goldman WE. Pulmonary infection by Yersinia pestis rapidly establishes a permissive environment for microbial proliferation. Proc Natl Acad Sci USA. 2012;109:3083-8.

95. Pechous RD, Sivaraman V, Price PA, Stasulli NM, Goldman WE. Early host cell targets of Yersinia pestis during primary pneumonic plague. PLoS Pathog. 2013;9:e1003679.

96. Sivaraman V, Pechous RD, Stasulli NM, Eichelberger KR, Miao EA, Goldman WE. Yersinia pestis activates both IL-1 $\beta$ and IL-1 receptor antagonist to modulate lung inflammation during pneumonic plague. PLoS Pathog. 2015;11:e1004688.

97. Peters KN, Dhariwala MO, Hughes Hanks JM, Brown CR, Anderson DM. Early apoptosis of macrophages modulated by injection of Yersinia pestis YopK promotes progression of primary pneumonic plague. PLoS Pathog. 2013;9:e1003324.
98. Pechous RD, Sivaraman V, Stasulli NM, Goldman WE. Pneumonic plague: the darker side of Yersinia pestis. Trends Microbiol. 2016;24:190-7.

99. Stasulli NM, Eichelberger KR, Price PA, Pechous RD, Montgomery SA, Parker JS, et al. Spatially distinct neutrophil responses within the inflammatory lesions of pneumonic plague. mBio. 2015;6:e01530-15.

100. Vagima Y, Zauberman A, Levy Y, Gur D, Tidhar A, Aftalion M, et al. Circumventing Y. pestis virulence by early recruitment of neutrophils to the lungs during pneumonic plague. PLoS Pathog. 2015;11:e1004893.

101. Pachulec E, Abdelwahed Bagga RB, Chevallier L, O'Donnell H, Guillas C, Jaubert J, et al. Enhanced macrophage M1 polarization and resistance to apoptosis enable resistance to plague. $\mathrm{J}$ Infect Dis. 2017;216:761-70.

102. Littman DR, Rudensky AY. Th17 and regulatory T cells in mediating and restraining inflammation. Cell. 2010;140:845-58.

103. Bi Y, Zhou J, Yang H, Wang X, Zhang X, Wang Q, et al. IL$17 \mathrm{~A}$ produced by neutrophils protects against pneumonic plague through orchestrating IFN- $\gamma$-activated macrophage programming. J Immunol. 2014;192:704-13.

104. Lin JS, Kummer LW, Szaba FM, Smiley ST. IL-17 contributes to cell-mediated defense against pulmonary Yersinia pestis infection. J Immunol. 2011;186:1675-84.

105. Pasztoi M, Bonifacius A, Pezoldt J, Kulkarni D, Niemz J, Yang $\mathrm{J}$, et al. Yersinia pseudotuberculosis supports Th17 differentiation and limits de novo regulatory $\mathrm{T}$ cell induction by directly interfering with $\mathrm{T}$ cell receptor signaling. Cell Mol Life Sci. 2017;74:2839-50.

106. Feodorova VA, Lyapina AM, Khizhnyakova MA, Zaitsev SS, Sayapina LV, Arseneva TE, et al. Humoral and cellular immune responses to Yersinia pestis Pla antigen in humans immunized with live plague vaccine. PLoS Negl Trop Dis. 2018;12: e0006511.

107. Derbise A, Hanada Y, Khalifé M, Carniel E, Demeure CE. Complete protection against pneumonic and bubonic plague after a single oral vaccination. PLoS Negl Trop Dis. 2015;9: $\mathrm{e} 0004162$.

108. Chiuchiolo MJ, Boyer JL, Krause A, Senina S, Hackett NR, Crystal RG. Protective immunity against respiratory tract challenge with Yersinia pestis in mice immunized with an adenovirus-based vaccine vector expressing V antigen. J Infect Dis. 2006;194:1249-57.

109. Heath DG, Anderson GW, Mauro JM, Welkos SL, Andrews GP, Adamovicz J, et al. Protection against experimental bubonic and pneumonic plague by a recombinant capsular F1-V antigen fusion protein vaccine. Vaccine. 1998;16:1131-7.

110. Osorio JE, Powell TD, Frank RS, Moss K, Haanes EJ, Smith SR, et al. Recombinant raccoon pox vaccine protects mice against lethal plague. Vaccine. 2003;21:1232-8.

111. Williamson ED, Eley SM, Griffin KF, Green M, Russell P, Leary SE, et al. A new improved sub-unit vaccine for plague: the basis of protection. FEMS Immunol \& Med Microbiol. 1995;12:22330.

112. Smiley ST. Current challenges in the development of vaccines for pneumonic plague. Expert Rev Vaccin. 2008;7:209-21.

113. WHO. Efficacy trials of plague vaccines: endpoints, trial design, site selection. WHO workshop in Paris, 2018. Available at http://www.who.int/blueprint/what/norms-standards/Pla gueVxeval_FinalMeetingReport.pdf?ua=1. Accessed Jan 2019.

114. FDA. Code of federal regulations. Title 21 (7), Chapter 1FBiologics. Part 601: Licensing, subpart H: Approval of biological products when human efficacy studies are not ethical or feasible. Revised 2018.

115. Cornelius CA, Quenee LE, Overheim KA, Koster F, Brasel TL, Elli D, et al. Immunization with recombinant V10 protects 
cynomolgus macaques from lethal pneumonic plague. Infect Immun. 2008;76:5588-97.

116. Simonet M, Berche P, Mazigh D, Veron M. Protection against Yersinia infection induced by non-virulence-plasmid-encoded antigens. J Med Microbiol. 1985;20:225-31.

117. Taylor VL. Oral immunization with a dam mutant of Yersinia pseudotuberculosis protects against plague. Microbiology. 2005;151:1919-26.

118. WHO. International meeting on preventing and controlling plague: the old calamity still has a future. Wkly Epidemiol Rec. 2006;28:278-84.

119. Stokell JR, Khan A, Steck TR. Mechanical homogenization increases bacterial homogeneity in sputum. J Clin Microbiol. 2014;52:2340-5.

120. Chanteau S, Rahalison L, Ralafiarisoa L, Foulon J, Ratsitorahina M, Ratsifasoamanana L, et al. Development and testing of a rapid diagnostic test for bubonic and pneumonic plague. Lancet. 2003;361:211-6.

121. Hinnebusch J, Schwan TG. New method for plague surveillance using polymerase chain reaction to detect Yersinia pestis in fleas. J Clin Microbiol. 1993;31:1511-4.

122. Tsukano H, Itoh K, Suzuki S, Watanabe H. Detection and identification of Yersinia pestis by polymerase chain reaction (PCR) using multiplex primers. Microbiol Immunol. 1996;40:773-5.

123. Parkhill J, Wren BW, Thomson NR, Titball RW, Holden MT, Prentice MB, et al. Genome sequence of Yersinia pestis, the causative agent of plague. Nature. 2001;413:523-7.

124. Loiez C, Herwegh S, Wallet F, Armand S, Guinet F, Courcol RJ. Detection of Yersinia pestis in Sputum by Real-Time PCR. J Clin Microbiol. 2003;41:4873-5.

125. Hänsch S, Cilli E, Catalano G, Gruppioni G, Bianucci R, Stenseth NC, et al. The pla gene, encoding plasminogen activator, is not specific to Yersinia pestis. BMC Research Notes. 2015;8 (535): $1-3$.
126. Riehm JM, Rahalison L, Scholz HC, Thoma B, Pfeffer M, Razanakoto LM, et al. Molecular and cellular probes. Mol Cell Probes. 2011;25:8-12.

127. Simonet M, Riot B, Fortineau N, Berche P. Invasin production by Yersinia pestis is abolished by insertion of an IS200-like element within the inv gene. Infect Immun. 1995;64:375-9.

128. Matero P, Pasanen T, Laukkanen-Ninios R, Tissari P, Tarkka E, Vaara M, et al. Real-time multiplex PCR assay for detection of Yersinia pestis and Yersinia pseudotuberculosis. APMIS. 2009;117:34-44.

129. Mölsä M, Hemmilä H, Katz A, Niemimaa J, Forbes KM, Huitu $\mathrm{O}$, et al. Journal of microbiological methods. J Microbiol Methods. 2015;115:89-93.

130. Feng N, Zhou Y, Fan Y, Bi Y, Yang R, Zhou Y, et al. Yersinia pestis detection by loop-mediated isothermal amplification combined with magnetic bead capture of DNA. Braz J Microbiol. 2018;49:128-37.

131. WHO. How to safely collect sputum samples from patients suspected to be infected with pneumonic plague. 2016. Technical Guidance. www.who.int/csr/disease/plague/en.

132. Tourdjman M, Ibraheem M, Brett M, DeBess E, Progulske B, Ettestad P, et al. Misidentification of Yersinia pestis by automated systems, resulting in delayed diagnoses of human plague infections-Oregon and New Mexico, 2010-2011. Clin Infect Dis. 2012;55:e58-e60.

133. Benavides-Montaño JA, Vadyvaloo V. Yersinia pestis resists predation by acanthamoeba castellanii and exhibits prolonged intracellular survival. Appl Environ Microbiol. 2017;83. https:// doi.org/10.1128/AEM.00593-17.

134. Markman DW, Antolin MF, Bowen RA, Wheat WH, Woods M, Gonzalez-Juarrero M, et al. Yersinia pestis survival and replication in potential ameba reservoir. Emerg Infect Dis. 2018;24:294-302.

135. D'Ortenzio E, Lemaître N, Brouat C, Loubet P, Sebbane F, Rajerison $\mathrm{M}$, et al. Plague: bridging gaps towards a better disease control. Med Et Mal Infect. 2018;48:307-17. 